\title{
The Influence of E-Service Quality on Customer Perceived Value, Customer Satisfaction and Loyalty in South Africa
}

\author{
Richard Chinomona \\ University of the Witwatersrand, School of Economic and Business Economics, South Africa \\ Email:rchinos@hotmail.com \\ GodreyMasinge \\ Vaal University of Technology, South Africa \\ Maxwell Sandada \\ University of Zimbabwe, Graduate School of Business, Zimbabwe
}

\section{Doi:10.5901/mjss.2014.v5n9p331}

\section{Abstract}

\begin{abstract}
While researches on online shopping behaviour have been steadily increasing, they seem to be a paucity of studies that investigate the importance of E-service quality; customer perceived value and customer satisfaction that result in customer loyalty in online shopping perspective. The present research is an attempt to fill this gap by examining the relative influence of three antecedents of customer loyalty - e-service quality, customer satisfaction, and customer perceived value on consumer online shopping behaviour, using a sample of consumers in Gauteng Province of South Africa. The central argument of this paper is that online shopping behavior can be understood from the strength of loyalty outcomes. Six hypotheses are posited and in order to empirically test these hypotheses, a sample data set of 150 was used. Three hypotheses were supported while three $(\mathrm{H} 1, \mathrm{H} 2$ and $\mathrm{H} 5)$ was rejected. Drawing from the study findings, this study provide tentative empirical support that online shopping behaviour can be influenced by e-service quality, customer satisfaction, loyalty and perceived value outcomes in Africa - a context that is often less researched on.
\end{abstract}

Keywords: E-service quality, Customer satisfaction, Customer perceived value, Customer loyalty, Online shopping behaviour, South Africa

\section{Introduction}

The use of information technologies has not only transformed the nature of services provided but it has also changed the process of providing the services (Paluch \& Blut, 2013). According to Johnson (2005), over the past years, the business to customer online shopping market has grown rapidly and changed the business pattern. In to differentiate themselves from competition, marketers have adopted electronic business in order to provide superior service that satisfies customers, creates customer value and ultimately develop customer loyalty (Lee, Petrick Crompton, 2007). E-service quality is one of the major drivers of online shopping, which refers to the level of user satisfaction with the technical and functional aspects of an Internet shopping website (Schaup, 2009). Delone and McLean (2003) suggest that system quality depends on various factors, including usability, availability, reliability, adaptability, and the response time of the system, which predict customer satisfaction in online shopping. A consumer's intention to use the Internet for purchase is largely dependent on the ease of use and trustworthiness of the shopping system (Brown \& Jayakody, 2009). The authors further state that in the internet shopping environment, system quality must support the consumer's purchasing activity by providing security and accessibility, which can also support costumer perceived value and customer satisfaction which predict customer loyalty in online shopping.

Online shopping has been recognized as an important aspect in creating profitability for companies, even though online environment is more complicated to establish a social connection between firms and customer due to the lack of physical environment, social distance between companies and customers (Head, 2001; Schijns, 2003) Among the factors that influence consumer loyalty there is consumer satisfaction that has considerable impact of customer loyalty (Castaneda, 2009). Although this relationship between customer satisfaction and loyalty is intuitive, few studies explore how to strengthen it in an online environment. Although perceived customer value has been recognized in marketing 
research as an important concepts in influencing preference and customer satisfaction (Cronin et al., 2000), most studies have examined customer value in the context of offline rather than online consumer behavior (Cronin et al., 2000; Overby \& Lee, 2006). As result customer loyalty and customer perceived value has recently received considerable attention in the field of marketing strategy (Ulga \& Eggert, 2006). This is because it plays an important role in predicting purchasing behavior (Chen \& Dibisky, 2003),

Therefore customers intention to purchase online is determined by factor such as e-service quality, customer perceived value, customer satisfaction and customer loyalty which altogether may provide significant and depth information and finding regarding their respective degree of influence and impact to the present problem. Yet, little research has been conducted in that regard has to determine and adequately provide a room of knowledge and important insight regarding this investigation (Cho \& Menor, 2010). Therefore the main purpose of this study is to examine the importance of e-service quality; customer perceived value and customer satisfaction that result in customer loyalty in online shopping. The investigation of relationships between these factors and their influence on customer loyalty will help equip managers to adapt their services and marketing efforts to influence positive consumer behavior (Lee et al., 2007).

The rest of the paper is presented as follows: The first section presents literature review of the constructs, followed by the development of the conceptual framework. Thereafter the research design methodology, results and findings, conclusion, limitation and recommendations of the study will be provided.

\section{Literature Review}

\subsection{Social Exchange Theory}

This study has adopted Social Exchange Theory in order to explain the nature of customer perceived value on online shopping. Social exchange theory (SET), with origins in behavioral psychology (Skinner, 1950). Social exchange theory contends that a basic motivation for interaction is the seeking of rewards and avoidance of punishments (Emerson, 1976). As such, Social Exchange Theory argues that attitudes and behaviors are determined by the rewards of interaction minus the penalty. This implies that rewarding customers for a particular positive action leads to intention to re-purchase.

\subsection{E-service quality}

E-service quality is generally defined as the difference between expected service and the perceived service (Gronroos, 1982). According to Zeithaml, Parasuraman and Malhotra (2002) e-service quality is defined as the extent to which website facilitates efficient and effective shopping, purchasing and delivery of products and services. The conceptualization of service quality has its roots in the expectancy disconfirmation theory (Collier \& Bienstock, 2006), so the evaluation of service quality results from comparing the perception of service received to prior expectation of what the service should provide (Choi et al., 2004). Generally online customers always expect equal or higher level of service quality that traditional channel customers (Lee \& Lin, 2005). A number of factors predict customer's perception of eservice quality. For example, Lee and Lin (2005) identified the main factors influencing customer perception of e-service quality in online shopping namely, degree of user friendliness, reliability and security, responsiveness helpfulness and trust mechanisms provided by a website. Fassnacht and Koese (2006) recommend that service providers should provide quality service because it is a source of competitive advantage. The success or failure of online business therefore depends the extent to which service providers provide quality service (Yang \& Jun, 2002)

\subsection{Customer perceived value}

Schiffman and Kanuk (2009) defined perceived value as the consumer's overall assessment of the utility of a product based on perceptions of what a customer receives. In online retailing settings, perceived customer value comes from not only the product itself, but also website itself, the internet channel as well as the process of finding, ordering, and receiving product (Keeney, 1999). Understanding and delivering customer value is seen as an effective way to retain customers and to develop and maintain long term relationships with customers (Roberts, 2000; Khalifa, 2004). According to Boshoff and du Plessis (2009), perceived value has its root in equity theory, which represents the trade-off between the benefits of the service and the financial, energy, time and mental costs that the customer incurs by in evaluating, obtaining and using a product.

However this simplification has been criticized for ignoring some important tangible construct (e.g. shopping 
experience, risk) and may be misleading inn measuring perceived customer value (Sinha \& Dessarbo, 1988). Perceived customer value has been recognized in marketing research as an important concept in influencing preference and customer satisfaction (Cronin et al., Overby \& Lee, 2006). However, in an online environment customers can find alternatives easily, therefore building long term relationships with customers presents a more difficult challenge for ecommerce firms.

\subsection{Customer satisfaction}

Kotler (2000) described satisfaction as a person's feeling of pleasure or disappointment resulting from comparing a product's perceived performance or outcome in relation to their expectations. Aderson and Scrinivasan (2003) defined esatisfaction as the content of the customer with respect to their prior purchasing experience with a given electronic commerce firm. Smith (2005) view customer satisfaction with e-service quality as the overall position or negative feeling regarding their purchasing experience from a given online shopping firm.

Satisfaction is important for establishing long term customer relationships and for further development of customer loyalty (Tsai et al., 2006). The relationship between satisfaction and loyalty seems intuitive and has been confirmed by many researchers (Taylor, 1992). However the strength of the relationship between satisfaction and loyalty has varied significantly under different conditions (Anderson \& Srinivasan, 2003).

\subsection{Customer loyalty}

Customer loyalty is defined as the proportion of times a purchaser chooses the some product or service in a specific category compared to the total number of purchases made by the purchaser in that category (Neal, 1999). Maximizing loyalty and the long term value of customer purchases is on the most important goal of website (Smith, 2005). It is considered difficult to gain customer loyalty on the internet (Gommans, Krishman \& Schefforld, 2003). In the previous studies satisfaction and service quality were usually used for explaining customer loyalty, but the relationships among them are complex and researchers have not reached consensus on this. Most marketing studies also seem to accept a theoretical framework in which quality leads to satisfaction which in turn influences purchasing behavior (Lin \&Sun, 2009). Satisfaction is the most relevant in the study of customer loyalty (Castaneda et al., 2009). In the online environment researchers have found that the overall satisfaction experienced by online customers reduces the perceived benefits of switching service provider, and thus yield strong repurchase intentions in the case of online e-retailing (Szymanski \& Hise., 2000). In other words a dissatisfied customer is more likely to search for information from other alternatives and is more likely to switch to competitors than is a satisfied customer (Anderson \& Sriniivasan, 2003). Therefore customer loyalty is one of the major drivers of success in e-commerce (Reichheld \& Schefter, 2000). Developing customer loyalty can be a major source of sustained growth and profit because loyal customers are price insensitive, they refer other customers to the business and they can make suggestions that help in improving service provision (Anderson \& Mittal 2000).

\section{Conceptual Model and Hypothesis Development}

Drawing from the extant literature from services marketing, a conceptual model is developed in Figure 1. The model consists of four constructs, that is, one predictor (e-service quality), two mediators (customer satisfaction and perceived customer value) and an outcome (customer loyalty). The relationship model shows that e-service quality has both direct and indirect relationships with customer loyalty. The provision of e-service quality influences customer satisfaction, which leads to customer loyalty or e-service impacts on perceived customer value and ultimately and this develops the loyalty of customers. Detailed explanations of the relationships among these variables are provided in the hypotheses developed hereafter. 
Figure 1. Conceptual model

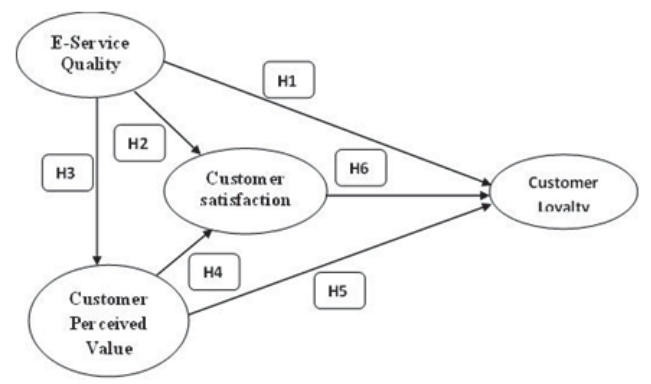

\subsection{E-Service Quality and Customer Loyalty}

Researchers generally agree that online e-service quality has a significant influence on the loyalty of customers on online shopping (Zeithaml et al., 2002). Hsu (2008) mention that there more a website is user-friendly and sufficiently informative, the more likely are customers to purchase and make re-purchase. Furthermore, Hsu's (2008) study revealed that all the aspects of e-service quality are significant predictors to consumer loyalty. Similarly, Jin et al. (2007) found that the reputation of an online shopping positively affects customer loyalty. Therefore the more the users tend to trust the eservice quality the more they are likely to become loyal to online business. Therefore, based on the empirical evidence, this study posits that:

$\mathrm{H1}$ : There is a positive relationship between e-service quality and customer loyalty.

\subsection{E-Service Quality and Customer Satisfaction}

Wu \& Lin, 2006 suggest that websites that are better and easy to use make consumer transactions easier and that attracts consumers to revisit or make a repeat purchase, which results customer satisfaction. Alpar (2001) identified two attributes of e-service quality that determine customer satisfaction with a website: ease of use (response speed, navigation support, use of new web technologies); and information content (quantity, quality, accuracy, customized information). The implication is that the more the website is user friendly, the more likely is the customer to engage in online shopping. Also, several empirical studies confirm that a higher level of service quality is related to a higher level of customer satisfaction (Andreassen \& Lindestad, 1998; Deng et al., 2010; Chang and Wang, 2011). Therefore, deducing from the Resource-Based View and empirical evidence, this study posits that:

$\mathrm{H} 2$ : There is a positive relationship between e-service quality and customer satisfaction

\subsection{E-Service Quality and Customer Perceived Value}

Yi (2000) believes that e-service quality is a vital determinant of customer perceived value. The nature of this e-service quality and customer value link is viewed as linear, demonstrating that higher levels of service quality result in higher levels of customer value (Pollack, 2008). The quality of the product or service and the benefits it offered are customer perceived value drivers (Bolton and Drew, 1991; Zeithaml et al.,, 1988, Shin \& Kim, 2008). Many studies support also support the positive association between e-service quality and customer perceived value (Andreassen \& Lindestad, 1998; Chang and Wang, 2011; Edward \& Sahadev, 2011). Therefore drawing from empirical evidence the following hypothesis is proposed:

H3: There is a positive relation between e-service quality and customer loyalty

\subsection{Customer Perceived Value and Customer Satisfaction}

Ample evidence exists in the literature to show that customer perceived value leads to customer satisfaction. Other scholars such as Edward and Sahadev (2011), and Hellier et al. (2003) also confirm the relationship between customer value and satisfaction. These findings can be buttressed by the results of other scholars which demonstrate the positive relationship between perceived value and customer satisfaction (Anderson \& Mittal, 2000; Chang and Wang, 2011; Edward \& Sahadev, 2011) and therefore, the following hypothesis is proposed:

$\mathrm{H} 4$ : High levels of perceived customer value have a positive influence on customer satisfaction. 


\subsection{Customer Perceived Value and Customer Loyalty}

Customer perceived value is crucial as it helps firms gain a competitive edge (Parasuraman et al., 1997). Customer perceived value on online shopping, that comprises of functional value, emotional value, and monetary value have significant effect on customer loyalty (Deng et al., 2010). It means that when users' functional value and emotional value are high, customers' loyalty becomes stronger (Rodgers \& Harris, 2003). Based on the empirical evidence the following hypothesis is proposed:

H5: High levels of customer perceived value positively influence customer loyalty.

\subsection{Customer Satisfaction and Customer Loyalty}

Satisfied customers visit a Web site more frequently due to enhanced loyalty because once an online customer has become accustomed to shopping at a particular site, his/her buying decision process becomes habitual (Alba\& Hutchinson, 2007).Customer satisfaction is therefore widely recognized as a key predictor to customer loyalty (Taylor \& Baker, 2004). Satisfied customers are more likely to tell others of their favorable experience and, thus, engage in positive word-of-mouth advertising (File \& Prince, 2002). Therefore, this study expects to see a positive relationship between customer satisfaction level and customer loyalty, this study posits that:

H6: The extent to which a customer is satisfied positively influences customer loyalty.

\section{Research Methodology}

\subsection{Sample and data collection}

The target population for the study was collected in South African consumer in Gauteng around Vaal triangle who purchased any consumer goods using website. Physical distribution and collection of questionnaire were used to collect data. This method has the advantage of speed, is less costly and the researcher has control over respondent. A random selection of the participating respondents was made. A total of 150 questionnaires were distributed, usable questionnaires were retrieved for the final data analysis,

\subsection{Measurement Instrument and Questionnaire Design}

This study consists of four variables of which E-service quality is measured by four-item scales all adapted from (Gronroos, \& Parasuraman, 1988). Customer perceive value used four-item scale measure all adopted from (Roberts \& Payne, 2001). Customer satisfaction used seven-item scale measure all adapted from (Devaraj, 2002), and "customer loyalty used a six-item scale measure adopted from (Cronin,J.J., \& Taylor, S.A. 1992). All the measurement items were measured on a five-point Likert-type scales that was anchored by $1=$ strongly disagree to $5=$ strongly agree to express the degree of agreement. Individual scale items are listed in Appendix 1.

\subsection{Respondent Profile}

Table 1 presents the description of the participants. The respondents were asked to report their demographic information, including gender, age, occupation, home internet, online shopping and online shopping in a month. The respondents were predominantly females (96\%) and male with a (54\%). The dominated age group is of between the age of 27-30 (37.3\%) followed by $31-39(30 \%)$ and $40 \&$ older is the lowest (4\%). About (41.3\%) of the respondents were students, (57\%) were employees, (36.7\%) were customers and (7.3\%) were others. About (60.7\%) use home internet and (39.3\%) don't have and (41.3\%) use online shopping while (58.7\%) don't. about (84\%) of respondents shop 1-4 times in a month, (14.7\%) 5-8 times in a month, (1.3\%) and 12+times a month. 
Table 1: Sample Demographic Characteristics

\begin{tabular}{|c|c|c|}
\hline Gender & Frequency & Percentage \\
\hline Male & 54 & $36 \%$ \\
\hline Female & 96 & $64 \%$ \\
\hline Total & 150 & $100 \%$ \\
\hline Age & Frequency & Percentage \\
\hline $19-22$ & 18 & $12 \%$ \\
\hline $23-26$ & 25 & $16.7 \%$ \\
\hline $27-30$ & 56 & $37.3 \%$ \\
\hline $31-39$ & 45 & $30 \%$ \\
\hline 40\&older & 6 & $4 \%$ \\
\hline Total & 150 & $100 \%$ \\
\hline Occupation & Frequency & Percentage \\
\hline Student & 62 & $41.3 \%$ \\
\hline Employee & 86 & $57 \%$ \\
\hline Customer & 55 & $36.7 \%$ \\
\hline Other & 11 & $7.3 \%$ \\
\hline Total & 150 & $100 \%$ \\
\hline Home internet & Frequency & Percentage \\
\hline Yes & 91 & $60.7 \%$ \\
\hline No & 59 & 39.3 \\
\hline Total & 150 & $100 \%$ \\
\hline Online shopping & Frequency & Percentage \\
\hline Yes & 62 & $41.3 \%$ \\
\hline No & 88 & 58.7 \\
\hline Total & 150 & $100 \%$ \\
\hline Shopping in a month & Frequency & Percentage \\
\hline 1-4 times & 126 & $84 \%$ \\
\hline 5-8 times & 22 & $14.7 \%$ \\
\hline $12+$ times & 2 & $1.3 \%$ \\
\hline Total & 150 & $100 \%$ \\
\hline
\end{tabular}

\section{Data Analysis}

\subsection{Structural Equation Modeling Approach}

In order to statistically analyze the measurement and structural models, this study used Smart PLS software for Structural Equation Modeling (SEM) technique (Ringle, Wende\& Will 2005). In SEM, the measurement model refers to the linkages between the latent variables and their manifest variables and the structural model captures the hypothesized causal relationships among the research constructs (Chin \&Newsted, 1999). SEM enables the simultaneous examination of both the path (structural) and factor (measurement) models in one model. In addition to that, Smart PLS combines a factor analysis with near regressions, makes only minimal assumptions, with the goal of variance explanation (high R- square) (Anderson, Schwager \& Kerns, 2006). Furthermore, Smart PLS supports both exploratory and confirmatory research, is robust to deviations for multivariate normal distributions, and is good for small sample size. Since the current study sample size is relatively small (150) Smart PLS was found more appropriate and befitting the purpose of the current study.

\subsection{Measurement Model}

A measurement model of the conceptual model with four latent variables was estimated. All constructs were modelled using reflective indicators since the previous study have modelled them the same. Construct reliability was assessed using Composite Reliabilities (CR) values and Cronbach's Alpha (CA) values. As indicated in Table 2, the CR and the CA values are all above 0.7 recommended by Hulland (1999). With values ranging from 0.8825 to 0.9071 for Composite reliability and from 0.8419 to 0.8765 for all Cronbach's alphas, this study can conclude that the scales are reliable. 
Table 2: Accuracy Analysis Statistics

\begin{tabular}{|c|c|c|c|c|c|c|c|c|}
\hline \multicolumn{2}{|c|}{$\begin{array}{l}\text { Research } \\
\text { Construct }\end{array}$} & $\begin{array}{c}\text { LV Index } \\
\text { Value }\end{array}$ & $\begin{array}{c}\text { R-Squared } \\
\text { Value }\end{array}$ & $\begin{array}{c}\text { Cronbach's } \alpha \\
\text { value }\end{array}$ & $\begin{array}{c}\text { C.R. } \\
\text { Value }\end{array}$ & $\begin{array}{c}\text { AVE } \\
\text { Value } \\
\end{array}$ & Communality & $\begin{array}{c}\text { Factor } \\
\text { Loading }\end{array}$ \\
\hline \multirow{4}{*}{ ESQ } & ESQ 1 & \multirow{4}{*}{4.3491} & \multirow{4}{*}{0.0000} & \multirow{4}{*}{0.8454} & \multirow{4}{*}{0.8959} & \multirow{4}{*}{0.6834} & \multirow{4}{*}{0.6834} & 0.7653 \\
\hline & ESQ 2 & & & & & & & 0.8719 \\
\hline & ESQ 3 & & & & & & & 0.8721 \\
\hline & ESQ 4 & & & & & & & 0.7919 \\
\hline \multirow{4}{*}{ CPV } & CPV 1 & \multirow{4}{*}{4.3040} & \multirow{4}{*}{0.6848} & \multirow{4}{*}{0.8419} & \multirow{4}{*}{0.8988} & \multirow{4}{*}{0.6947} & \multirow{4}{*}{0.6947} & 0.9129 \\
\hline & CPV 2 & & & & & & & 0.9116 \\
\hline & CPV 3 & & & & & & & 0.8685 \\
\hline & CPV 4 & & & & & & & 0.6001 \\
\hline \multirow{7}{*}{ CS } & CS 1 & \multirow{7}{*}{4.3706} & \multirow{7}{*}{0.4735} & \multirow{7}{*}{0.8423} & \multirow{7}{*}{0.8825} & \multirow{7}{*}{0.5244} & \multirow{7}{*}{0.5244} & 0.7710 \\
\hline & CS 2 & & & & & & & 0.7821 \\
\hline & CS 3 & & & & & & & 0.8062 \\
\hline & CS 4 & & & & & & & 0.8241 \\
\hline & CS 5 & & & & & & & 0.7618 \\
\hline & CS 6 & & & & & & & 0.5264 \\
\hline & CS 7 & & & & & & & 0.5276 \\
\hline \multirow{6}{*}{$\mathrm{CL}$} & $\overline{C L} 1$ & \multirow{6}{*}{4.3184} & \multirow{6}{*}{0.5484} & \multirow{6}{*}{0.8765} & \multirow{6}{*}{0.9071} & \multirow{6}{*}{0.6208} & \multirow{6}{*}{0.6208} & 0.7292 \\
\hline & CL 2 & & & & & & & 0.6904 \\
\hline & CL 3 & & & & & & & 0.7995 \\
\hline & CL4 & & & & & & & 0.7796 \\
\hline & CL5 & & & & & & & 0.8536 \\
\hline & $\overline{C L 6}$ & & & & & & & 0.8607 \\
\hline
\end{tabular}

Note: ESQ = E-Service Quality; CPV = Customer Perceived Value; CS = Customer Satisfaction; CL = Customer Loyalty

C.R.: Composite Reliability; AVE: Average Variance Reliability;

* Scores: 1 - Strongly Disagree; 3 - Neutral; 5 - Strongly Agree

Convergent validity (internal consistence) was assessed using the average variance extracted (AVE) measure and Item loading values. According to Fornell and Lacker's (1981) the suggested benchmark should be 0.5 . As an be noted again in Table 2 and Figure 2, all the item loadings and AVE values reached the recommended benchmark - implying that all items converged well on the construct they were supposed to measure and hence confirming the existence of convergent validity.

Table 3: Inter-Construct Correlations and Shared Variance

\begin{tabular}{|l|c|c|c|c|}
\hline \hline RESEARCH CONSTRUCTS & CL & CPV & CS & ESQ \\
\hline Customer Loyalty (CL) & 1.000 & & & \\
\hline Customer Perceived Value (CPV) & 0.5543 & 1.000 & & \\
\hline Customer Satisfaction (CS) & 0.7377 & 0.6881 & 1.000 & \\
\hline E-Service Quality (ESQ) & 0.4614 & 0.8275 & 0.5697 & 1.000 \\
\hline
\end{tabular}

Note: CL= Customer Loyalty; CPV = Customer perceived Value; CS = Customer Satisfaction; ESQ = E-Service Quality.

Diagonal elements are the square root of Average Variance Extracted. The other values are the inter-construct correlations

To assess discriminant validity the AVE of the construct should be greater than the shared variance between the construct and the other model constructs (Chin, 1998). Table 3 lists the correlation matrix with correlation among constructs and the square root AVE on the diagonal. As shown in Table 3, the diagonal elements are greater than the offdiagonal elements in the corresponding rows and columns, therefore confirming that discriminant validity indeed exist.

\subsection{Structural Modeling Results}

The structural model was tested using the loadings and significance of the path coefficients (indicate the strengths of relationships between dependent and independent variables), and the $\mathrm{R}^{2}$ value (the amount of variance explained by 
independent variables). The statistical significance of each path was estimated using a Smart PLS bootstrapping method utilizing 300 resamples to obtain t-values (Chin, 1998). Figure 2 and Table 4 presents the results of the PLS analysis on the structural model along with the path estimates and t-values. Support for the study hypotheses, which are labeled on their corresponding paths in Figure 2, could be ascertained by examining the directionality (positive or negative) of the path coefficients and the significance of the t-values. The standardized path coefficients are expected to be at least 0.2 , and preferably greater than 0.3 (Chin 1998).

Figure 2: Measurement and Structural Model Results

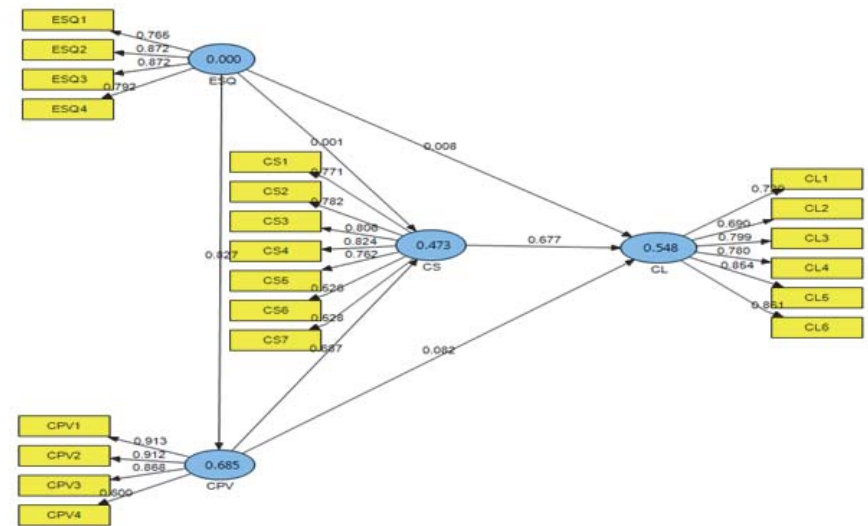

Note: ESQ = E-Service Quality; CPV=Customer Perceived Value; CS= Customer Satisfaction; CL = Customer Loyalty.

$\mathrm{R}^{2}$ represent the amount of variance explained by the independent variables. Figure 2 indicates that customer satisfaction, customer perceived value and customer loyalty explain at least about $47.3 \%, 68.5 \%$ and $54.8 \%$ of the model respectively. The T-statistics provided in Table 4 indicate that half of the values are above two (2), therefore signifying that half of the proposed relationships are significant. The statistical significance of the path coefficients allows us to see which hypotheses were supported. All in all, the paths had positive and negative effects and supported and rejected some of proposed hypotheses. Table 4 provides the proposed hypotheses and the path coefficients, and indicates the supported hypotheses.

Table 4: Results of Structural Equation Model Analysis

\begin{tabular}{|l|c|c|c|c|}
\hline \hline \multicolumn{1}{|c|}{ Proposed Hypothesis Relationship } & Hypothesis & Path Coefficients & T-Statistics & $\begin{array}{c}\text { Rejected I } \\
\text { Supported }\end{array}$ \\
\hline E-Service quality (ESQ) $\rightarrow$ Customer Loyalty (CL) & H1 & -0.008 & 0.0674 & Rejected \\
E-Service Quality (ESQ) $\rightarrow$ Customer Satisfaction (CS) & H2 & -0.001 & 0.0061 & Rejected \\
E-Service Quality (ESQ) $\rightarrow$ Customer perceived Value (CPV) & H3 & 0.827 & 20.6056 & Supported \\
Customer Perceived Value (CPV) $\rightarrow$ Customer satisfaction (CS) & H4 & 0.687 & 5.0946 & Supported \\
Customer Perceived Value (CPV) $\rightarrow$ Customer Loyalty (CL) & H5 & -0.082 & 0.5809 & Rejected \\
Customer Satisfaction (CS) $\rightarrow$ Customer Loyalty (CL) & H6 & $\mathbf{0 . 6 7 7}$ & 7.7719 & Supported \\
\hline \hline
\end{tabular}

Note: ESQ = E-Service Quality; CPV=Customer Perceived Value; CS = Customer Satisfaction; CL = Customer Loyalty.

Smart PLS software does not provide goodness-of-fit measures for the full path model as like LISREL and AMOS, but it provides only $\mathrm{R}^{2}$ values for the dependent variables. However, a method to calculate a global goodness-of-fit (GoF) measure was proposed by Amato, Vinzi and Tenenhaus (2004), and this method takes into account both the quality of the measurement model and the structural model (Tenenhaus, Vinzi, Chatelin\&Lauro, 2005; Streukens, 2008). The global goodness-of-fit (GoF) statistic was calculated using the following equation:

\section{$\mathrm{GoF}=\sqrt{\overline{\mathrm{AVE}}=\overline{\mathrm{R}^{2}}}$}

Where $\overline{A V E}$ represent the average of all AVE values for the research variables while $\overline{\mathrm{R}^{2}}$ represents the average of all $R^{2}$ values in the full path model

The calculated global goodness of fit (GoF) is 0.54 , which exceeds the recommended threshold of $\mathrm{GoF}>0.36$ 
suggested by Wetzels, Odekerken-Schröder\& van Oppen (2009). Thus, this study concludes that the research model provides an overall goodness of fit.

\section{Discussion of Results}

The results in Table 4 and Figure 2 provide support for three (3) hypotheses $(\mathrm{H} 3, \mathrm{H} 4$, and $\mathrm{H6}$ ) and reject threehypotheses $(\mathrm{H} 1, \mathrm{H} 2$ and $\mathrm{H} 5)$. Hypothesis 1 posited a positive relationship between e-service quality and customer loyalty. However, the result in Table 4 and Figure 2, indicates that they is a negative $(\beta=-0.008)$ but insignificant $(t=0.0674)$ relation between e-service quality and customer loyalty. Therefore, $\mathrm{H} 1$ is rejected. Hypothesis 2 posited a positive association between e-service quality and customer satisfaction. The result in Table 4 and Figure 2 indicate that they is a negative $(\beta=0.001 ; t=0.0061)$ relation between e-service quality and customer satisfaction. Therefore, $\mathrm{H} 2$ is rejected. The standardized coefficients of e-service quality and customer perceived value ( $\beta=0.827 ; t=20.6056)$ is positive and significant. This is consistent with the prediction of $\mathrm{H} 3$ and is supported. Thus, a higher level of e-service quality is associated with higher levels of customer perceived value. Consistent with Hypothesis 4, results indicated that higher levels of customer perceived value will lead to higher levels of customer satisfaction ( $\beta=0.687 ; t=5.0946)$. Therefore $H 4$ is supported. Hypothesis 5 posited a positive relationship between customer perceived value and customer loyalty. However, the result in Table 4 and Figure 2, indicates that they is a negative $(\beta=-0.082)$ but insignificant $(t=0.5809)$ relation between customer perceived value and customer loyalty. Therefore, $\mathrm{H} 5$ is rejected. Finally, results in Table 4 and Figure 2, are in line with $\mathrm{H} 6$ and support the reasoning that the higher the level of customers satisfaction, the higher customer loyalty ( $\beta=0.677 ; t=7.7719)$. Therefore, $\mathrm{H} 6$ is strongly supported.

\subsection{Conclusion}

The purpose of this study was to investigate the influence of e-service quality, customer satisfaction, and customer perceived value on customer loyalty in online shopping. In particular, six hypotheses were postulated. To test the proposed hypotheses, data were collected from Gauteng Province in South Africa. The empirical results supported the three posited research hypotheses in a significant way $(\mathrm{H} 3, \mathrm{H} 4$ and $\mathrm{H} 6$, while three hypotheses $(\mathrm{H} 1, \mathrm{H} 2$ and $\mathrm{H} 5)$, although supported was insignificant. However, $\mathrm{H} 1, \mathrm{H} 2$ and $\mathrm{H} 5$ which hypothesized to be positive were found to be negative and insignificant.

Important to note about the study findings is the fact that e-service quality has the strongest influence on customer perceived value (0.827) and followed by customer perceived value (0.687) and customer satisfaction. The paradox is on customer perceived value which was found to be negatively related to customer loyalty. One might expect that when customer perceived value in online shopping, the higher the likelihood of a customer to have loyalty, hence a positive there is a positive relationship between customer perceived value and customer satisfaction as well customer satisfaction and customer loyalty.

\subsection{Implications of the study}

One of the challenging tasks that online seller face is how to enhance customer satisfaction and loyalty. As suggested by our model, customer loyalty will develop if the e-service quality, customer satisfaction, and customer perceived value is well managed. Therefore, online service marketing strategies may be more fruitful through focusing on these psychological processes. Customer satisfaction is the greatest impact among these three factors. Thus, it is important for a website service provider to have a satisfying website to increase customer loyalty. Therefore e-service provider must be concerned about the quality of their service and highlight customer value. Particularly, they satisfy customers' value through providing good and reliable functions, giving a more pleasant interface.

As the result Trust appears to be important for both customer satisfaction and loyalty formation, which implies that, in order to attract more current customers to repurchase online, the service providers must try to establish an impression that they are honest to their customers and care about customers' needs, which can then enhance the degree of customers' perceptions of trust. The research results indicate that customer perceived value significantly affects customer loyalty. Therefore, an increasing in customer perceived value is an important marketing tool to maintain customer satisfaction in online buying. Based on the finding of this study e-service quality influences customer perceived value in online buying, That is, an increase in the quality of the website service enhance the customers satisfaction, and improve the customers perceived value of the service. Therefore, the current study investigate this contentious issues in an often most neglected research context and the findings of this empirical study are expected to provide fruitful new insights and 
implications to both academicians and practitioners across the globe.

\subsection{Limitations and Future Research}

Although this study makes significant contributions to both academia and practice, it was limited in some ways, and therefore some future research avenues are suggested. First, the data were gathered from Gauteng Province of South Africa and the sample size of 150 is relatively small. Perhaps, the results would be more informative if the sample size is large and data gathered from the other eight provinces of the country are included. Therefore, future studies may be conducted by using data from other provinces in South Africa. Second, perhaps too, future studies should not be limited to South Africa, but rather consider extending this research to other African countries such as Nigeria for results comparison. Future studies can also extend the current study conceptual framework by studying the effects of a larger set of variables. For instance, the influence of functional value, monetary value, and emotional value could be investigated. Above and beyond, this will immensely contribute new knowledge to the existing body of customer loyalty and satisfaction on online shopping behaviour in South Africa.

\section{References}

Alba, J., Hutchinson, W. (2007). Dimensions of consumer expertise. Journal of Consumer Research, 13, 411-454.

Anderson, E.W., Mittal, V. (2000). Strengthening the satisfaction-profit chain. Journal of Service Research, 3(2), $107-120$.

Anderson, E.W., Sullivan, M.W. (2003). The antecedents and consequences of customer satisfaction for the firm. Marketing science, Vol. 12(2):125-43.

Anderson, E.W., Mittal, V. (2002) Strengthening the satisfaction chain. Journal of service research, I3, 107-120.

Anderson, R.E, Srinivasan, S.S (2003). E-satisfaction and e-loyalty: A contingency framework, Psychology and Marketing, 20(2):23-38.

Andreassen, T.W., Lindestad, B. (1998), Customer loyalty and complex services, International Journal of Service Industry Management, 9(1):7-23.

Blake, B.F., Neuendorf, K.A., Valdiserri C.M. (2005). Tailoring new websites to appeal to those most likely to shop online. Technovation, 25(10):1205-15.

Boshoff, C., Du Plessis, F. (2009). Services Marketing: A Contemporary Approach. Juta and Company Ltd. Cape Town.

Boulding, W., Kalra, A., Staelin R., Nadzeithanml, V.A. (1993), A dynamic process model of service quality: from expectation to behavioural intention, Journal of marketing research, 30(1):7-27.

Brynjolfsson, E., Smith, M.D (2000), Frictionless commerce a comparison of internet and conventional retailers. Management Science, 46(4):563-85.

Caruana, A (2002), Service loyalty: the effects of service quality and the mediating role of customer satisfaction, European Journal of Marketing, 36(7/8):811-28.

Castaneda, J.A., Rodriguez, M.A., Lugue, T. (2009). Attitude hierarchy of effects in online user behavior, Online Information Review, 33(1):7-21.

Chang Hsin Hsin., Wang Hsin-Wei, (2011). The moderating effect of customer perceived value on online shopping behaviour, Online Information Review, Vol. 35(3):333 - 359

Chen, Z., Dubisky, A.J. (2003) A conceptual model of perceived customer value in e-commerce: a preliminary investigation: Psychology and Marketing, 20(4):323-47.

Cho, Y.K., Menor, L.J. 2010. Toward a Provider-Based View on the Design and Delivery of Quality E-Service Encounters. Journal of Service Research, 13(1):83-95.

Choi, K.S Cho, W.H., Lee, H., Kim, C. (2004). The relationships among quality, value, satisfaction and behavioral intention in health care provider choice: A South Korean study, Journal of Business Research, 57(80:913-21.

Collier, J.E., Bienstock C.C (2006) Measuring service quality in e-retailing. Journal of Service Research, 8(3):260-75.

Deng, Z., Lu, Y., Wei, K.K., Zhang, J. (2010) Understanding customer satisfaction and loyalty: an empirical study of mobile instant messages in China. International Journal of Information Management, Forthcoming issue, 30 (4):289-300

Devaraj, S., Fan, M. Kohli, R. (2002), Antecedent of B2C channel satisfaction and preference validating e-commerce metrics, Information Systems Systems Research, 13(3):316-33.

Edward M., Sahadev S. (2011) Role of switching costs in the service quality, perceived value, customer satisfaction and customer retention linkage, Asia Pacific Journal of Marketing and Logistics, 23(3):327 -345.

Edward M., Sahadev, S. (2011) Role of switching costs in the service quality, perceived value, customer satisfaction and customer retention linkage, Asia Pacific Journal of Marketing and Logistics, 23(3):327 - 345

Fassnacht, M., Koese, I. (2006). Quality of Electronic Services: Conceptualizing and Testing a Hierarchical Model. Journal of Service Research, 9: 19

Fornell C, Johnson MD., Anders, On, EW., Cha, J., Bryant, BE. (2000). The American customer satisfaction index: nature, purpose, and findings. Journal of Marketing, 60(4):7-18.

Frambach, R.T., Roest, H.C.A., Krishnan, T.V. (2007), The impact of consumer internet experience on channel preference and usage 
intentions across the different stage of the buying process", Journal of Interactive Marketing, 21(2):26-41

Gommans, M., Krishman, K.S., Schefforld, K.B. (2001). From brand loyalty to e-loyalty: a conceptual framework', Journal of Economics and social Research, 3(1):43-59.

HSU, S.-H., 2008. Developing an index for online customer satisfaction: adaptation of American customer satisfaction index. Expert Systems with Applications 34:3033-3042.

Jin, B., Park, J. Y., Kim, J. (2007). Cross-cultural examination of the relationships among firm reputation, e-satisfaction, e-trust, and eloyalty. International Marketing Review, 25(3), 324-337.

Lai F., Griffin M., Babin B. J, (2009), How quality, value, image, and satisfaction create loyalty at a Chinese telecom, Journal of Business Research 62:980-986.

Lee, G.G., Lin, H.F. (2005), Customer perceptions of e-service quality on online shopping, International Journal of Retail and Distribution Management, 33(2):161-76.

Lee,E.J., Overby, J.W. (2004). Creating value for online shoppers: implications for satisfaction and loyalty", journal of consumer satisfaction, Dissatisfation and complaining Behavoir, 17(1):54-67.

Lee. S.Y; Petrick. J.F., Crompton. J. (2007). The Roles of Quality and Intermediary Constructs in Determining Festival Attendees' Behavioral Intention. Journal Travel Research, 45: 402

Newman, J.W., Werbel, R.A. (2003), Mutivariate analysis of brand loyalty for major household appliances, Journal of Marketing Research, 10(4): 404-9.

Oliver, R. L. (2009). Whence consumer loyalty. Journal of Marketing, 63:33-44.

Oliver, R.L (2000). A cognitive model of the antecedents and consequences of satisfaction decision, Journal of Marketing Research, 17(4):460-9.

Paluch, S., Blut, B. (2013). Service Separation and Customer Satisfaction: Assessing the Service Separation/Customer Integration, Journal of Service Research 16: 415

Payne, A., Holt, S., Frow, P. (2001), Relationship value management: exploring the integration of employee, customer and shareholder value and enterprise performance models, Journal of Marketing management, 17(33):785-815.

Pollack, B.L. (2008). The nature of the service quality and satisfaction relationship: empirical evidence for the existence of satisfiers and dissatisfies, Managing Service Quality, 18(6):537-58

Roig, JCF., Garcia, JS., Tena MAM. (2009). Perceived value and customer loyalty in financial services. Service. Industry Journal, 29:775-789.

Saha G. C; Theingi, (2009), Service Quality, Satisfaction, and Behavioural Intentions, Managing Service Quality, 19:350-372.

Srinivasan, S.S., Anderson, R., Ponnavolu, K. (2002), Customer loyalty in e-commerce an exploration of its antecedents and consequences, Journal of Retailing, 78(1):41-50.

Vesel. P., Zabkar., Z.M. (2009). Customer loyalty through the mediating role of satisfaction in the DIY retail loyalty program. Journal of Retailing and Consumer Services 16:396-406

Vinayek, R., Jindal, J. (2011). An Empirical Investigation of Key Antecedents of Customer Preference of Internet Banking in Indian Context. Asia Pacific Business Review, 17: 63.

Woodruff, R.B. (2007). Customer value: The next source of competitive advantage. Journal of the Academy of Marketing Science, 25(2), 139-153.

Zeithaml, V.A., Parasuraman, A., Maihotra, A. (2002), Service quality delivery through websites: a critical review of extant knowledge, Journal of the Academy of Marketing Science, 30(30):475. 